\title{
Higher education's contribution to graduate employability and the social good
}

BOOK TITLE:

Universities, employability and human development

\section{BOOK COVER:}

UNIVERSITIES,

EMPLOYABILITY

AND HUMAN

DEVELOPMENT

\section{AUTHORS:}

Melanie Walker and

Samuel Fongwa

ISBN:

9781137584519 (hardcover)

\section{PUBLISHER:}

Palgrave MacMillan, London; USD79.99

\section{PUBLISHED:}

2017

\section{REVIEWER:}

Delia Marshall

\section{AFFILIATION:}

Physics Department, University of the Western Cape, Cape Town, South Africa

\section{EMAIL:}

dmarshall@uwc.ac.za

\section{HOW TO CITE:}

Marshall D. Higher education's contribution to graduate employability and the social good. S Afr J Sci. 2018;114(1/2), Art. \#a0250, 2 pages. http://dx.doi. org/10.17159/sajs.2018/a0250

(C) 2018. The Author(s). Published under a Creative Commons Attribution Licence.
In contemporary times of globalisation, massification of higher education and economic, social and environmental challenges, there has been renewed debate internationally on the purposes of higher education. In South Africa too, higher education's role in society has been thrown into sharp focus by the student protests of 2015-2016. Walker and Fongwa's well-timed book tackles this pressing question of higher education's role in society.

The book has its origin in an international project on higher education and employability, and presents the South African part of the study, based on case studies of four universities that represent a range of institutional types. Drawing on interviews and surveys with students, lecturers, support officers and employers, the study uses qualitative and quantitative data to build a picture of how employability is perceived, and what universities are doing to develop graduates - not merely for the workplace but also for broader critical citizenship.

The book's first key contribution is a critique of dominant economic conceptualisations of employability. Of course, in a context like South Africa, with high levels of unemployment and a sluggish economy, one cannot completely dismiss the economic purposes of higher education, both for individuals' lives and for economic growth. However, Walker and Fongwa argue that employability needs to involve more than individuals' entry into the workplace, or contributions to human capital and economic growth. Such conceptualisations are limited, they argue, and need to be enlarged by a conceptualisation of employability that encompasses public good values, such as concerns of social justice, inequality and poverty reduction. This enlarged view of employability, encompassing students' preparation for both work and society, is especially important in a context, like South Africa, of huge inequality and poverty.

In considering the significant ways in which individuals can be shaped by their experiences of higher education, the authors draw on the work of Dreze and Sen ${ }^{1}$, providing a perspective on how education can be instrumentally, intrinsically and socially significant for individuals. This perspective is valuable for thinking about the 'public good' purposes of higher education because it foregrounds the important role that education plays in developing individuals' capacity to deliberate critically about social concerns, to engage with diversity, and to actively engage around social inequalities. All these are crucial capacities for building critical citizens and for strengthening a young democracy such as that in South Africa.

The power of Walker and Fongwa's approach is that they extend the conceptualisation of the 'public good' from its philosophical origins to questions of what this might mean practically for higher education. They do this by linking public good with the capabilities approach, drawing on the work of economist Amartya Sen ${ }^{2}$ and related work on human development. For Sen, 'capabilities' relate to the opportunities that individuals have for being able to realise outcomes that they value. These opportunities are shaped and mediated by what are termed 'conversion factors' - the structural arrangements which differentially shape the opportunities for individuals based on their social backgrounds. These theoretical ideas, as well as concepts drawn from Martha Nussbaum's work ${ }^{3}$, form the theoretical basis of the study.

The research findings are reported in several chapters which present quantitative data alongside rich interview data. The first part examines final-year student and academic staff conceptions of employability. Perhaps not surprisingly, the predominant focus is on knowledge and practical skills. Walker and Fongwa argue that, while obviously knowledge and skills are crucial, 'without wider commitments to the public good and the good lives of others both may become individualistic and socially hollowed out' ( $p .102)$. The study also looks at conversion factors shaping graduate employability; these include race, social class, university reputation and field of study.

From perceptions of employability, the focus then returns to students' experiences of higher education itself. With the current trend towards snappily worded university mission statements and Charters of Graduate Attributes, I found this section particularly interesting. Here, they draw on Nussbaum's notion of 'freedom education' premised on the development of three core capabilities: critical examination, global citizenship and narrative imagination. They examine institutional documents and policies, and interview academic staff and students to get a sense of how educational arrangements in the institutions are set up to develop these capabilities. Not surprisingly they find that, while most universities claim in their mission statements to focus on broader social good and citizenship graduate attributes, in fact these attributes are seldom embedded in the curriculum and pedagogy itself, but are relegated to the co-curricular programme, if addressed at all. About their findings they caution:

\footnotetext{
For a society with so much inequality and social injustice, any university curriculum and pedagogy that focuses on skills and employability without an active focus on issues of exclusion, social responsiveness and democratic citizenship limits the potential of universities in contributing to human development. (p.130)
}

The last empirical section in the book draws on the fascinating narratives of 25 students, interviewed in their final year at university and then again about 1 year after graduation. These careful narratives, which follow students as they make their way into the world after graduation, bring to life the theoretical ideas explored in the book and point to ways in which institutions might do more 'to enable the best possible conditions for all their students to aspire and achieve' (p.213). They also present a more nuanced picture of graduate entry to the workplace than the large-scale graduate destination studies - which currently dominate this field - are able to provide. The final chapter then engagingly draws together the earlier theoretical and empirical sections to offer a practical way 
forward for institutions in developing graduates not only for work but for participation in society.

This is a theoretically and empirically significant book. For researchers in higher education studies or sociology of education, it will serve as a valuable handbook providing comprehensive overviews of philosophy of education, the capabilities approach, the higher education policy landscape, and graduate employability trends. The empirical aspects will also be of great interest to researchers and practitioners.

Walker and Fongwa argue for curricula and pedagogical practices that more explicitly prepare graduates to engage productively in the South African context of inequality and poverty. Student voices in this study, too, express that more could be done to promote social engagement and citizenship values. This has obvious resonances with the \#FeesMustFall student calls for curricula transformation and Africanisation. However, it was interesting that the students in this study were not suggesting an entire overhaul of curricula or contesting discipline knowledge itself. Although the empirical stage of this research project predated the student protests, I could not help feeling that I wanted to read more about how these authors would engage with these developments. No doubt this is something they will be exploring down the line.

This book is a must-read for higher education lecturers, policymakers and university managers. It articulates a powerful framework for enlarging how we commonly think about employability. It provides tangible ways forward for institutions that wish to take seriously the public good purposes of higher education and it offers a more expansion vision of higher education for tackling social justice concerns globally.

\section{References}

1. Dreze J, Sen A. India: Development and participation. Oxford: Oxford University Press; 2002. https://doi.org/10.1093/acprof:0so/9780199257492.001.0001

2. Sen A. Development as freedom. Oxford: Oxford University Press; 1999.

3. Nussbaum M. Creating capabilities: The human development approach. Cambridge, MA: Belknap Press; 2011. https://doi.org/10.4159/harvard.9780674061200 